\title{
Emotion-Induced Retrograde Amnesia Is Determined by a 5-HTT Genetic Polymorphism
}

\author{
Bryan A. Strange, Marijn C. W. Kroes, Jonathan P. Roiser, Geoffrey C. Y. Tan, and Raymond J. Dolan \\ Wellcome Trust Centre for Neuroimaging, Institute of Neurology, London WC1N 3BG, United Kingdom
}

A polymorphism in the human serotonin transporter (5-HTT) gene is implicated in susceptibility to anxiety and depression and in enhanced emotion-induced activation in the amygdala. A role for 5-HTT polymorphism in the emotional modulation of human episodic memory has yet to be demonstrated. Here, we demonstrate that whereas emotional memory for aversive events per se is not influenced by 5 -HTT polymorphism, an emotion-induced retrograde amnesia is expressed solely in the presence of the short allele. The findings indicate a critical role for the serotonin system in emotion-mediated memory disruption.

Key words: serotonin (5-HT); 5-HTT; polymorphism; emotion; memory; retrograde amnesia

\section{Introduction}

A functional deletion/insertion polymorphism within the serotonin transporter-linked promoter region (5-HTTLPR) produces short (" $\mathrm{s}$ ") or long ("l") repetitive sequences, which influences 5-HTT protein expression and function (Heils et al., 1996, 1997; Canli and Lesch, 2007). Specifically, the low-expressing s allele form of the human 5-HTT gene is associated with relatively less 5-HTT mRNA transcription and 5-HTT binding, reduced platelet 5-HT reuptake (Heils et al., 1996; Heinz et al., 2000; Hariri and Holmes, 2006), and reduced 5- $\mathrm{HT}_{1 \mathrm{a}}$ binding in the brain (David et al., 2005). A functional role for this polymorphism in human emotional regulation is suggested by an association between the s allele and anxiety-related traits as well as neuroticism (Canli and Lesch, 2007). Emotional learning contributes to the development of anxiety disorders (Ressler and Mayberg, 2007), and modulation of episodic memory by emotion is amygdala dependent (Cahill et al., 1995; Strange et al., 2003). Furthermore, enhanced amygdala reactivity to emotional stimuli is seen in s carriers (Hariri et al., 2002), an effect mirrored by 5-HTT availability (Rhodes et al., 2007). On this basis, we hypothesized a functional role for a 5-HTT polymorphism in emotional modulation of human episodic memory.

We used an established experimental procedure that indexes memory enhancement and impairment consequent on the occurrence of emotionally aversive events (Strange et al., 2003). In this task, there is enhanced memory for emotional (E) stimuli, which contrasts with a relative amnesia for stimuli preceding emotional events (E-1 stimuli) as tested by subsequent free recall (Strange et al., 2003). Our experimental question was whether

\footnotetext{
Received Feb. 25, 2008; revised April 29, 2008; accepted May 22, 2008.

This work was supported by a program grant from the Wellcome Trust to R.J.D. We thank A. Pine for help in data collection.

The authors declare no competing financial interests.

Correspondence should be addressed to Bryan A. Strange, Wellcome Trust Centre for Neuroimaging, 12 Queen Square, London WC1N 3BG, UK. E-mail: bstrange@fil.ion.ucl.ac.uk.

D01:10.1523/JNEUROSCI.0834-08.2008

Copyright $\odot 2008$ Society for Neuroscience $\quad$ 0270-6474/08/287036-04\$15.00/0
}

these effects differ between subjects homozygous for $\mathrm{s}$ or $\mathrm{l}(\mathrm{s} / \mathrm{s}$ and $1 / 1$, respectively), where we predicted an enhancement of emotional modulation of memory in $\mathrm{s} / \mathrm{s}$ compared with $\mathrm{l} / \mathrm{l}$ subjects.

\section{Materials and Methods}

Twenty-eight native English-speaking Caucasian subjects, half s/s and half $1 / 1$, matched for age, sex, and intelligence quotient (14 male, 14 female; age range, 19-51 years; mean age, 27.86) participated in the study. Subjects and experimenter were blind to genotype. The study had full ethical approval. Thus, we tested two subject groups, $s / \mathrm{s}$ and $1 / 1$, on a memory task (Strange et al., 2003) in which subjects viewed 38 lists of 14 nouns presented visually at a rate of one noun every $3 \mathrm{~s}$ (stimulus duration, $1 \mathrm{~s}$ ). Subjects engaged in a shallow encoding task, making a keyboard response to each word to indicate whether the first letter contained an enclosed space. For each list, all nouns were of the same semantic category. Of these, 12 were emotionally neutral and were all presented in the same font, referred to as control nouns. The first five nouns in each list were always control nouns, to set context. The emotional oddball (E) was aversive in content but perceptually identical to control nouns. An emotionally neutral perceptual oddball $(\mathrm{P})$, which controlled for nonspecific oddball effects, was presented in a novel font (Fig. 1a). The presentation of each 14-word list was followed by a $30 \mathrm{~s}$ distraction task during which subjects were instructed to count backwards in threes (out loud), starting at a number between 80 and 117 displayed on screen. The distraction task was followed immediately by instructions to free-recall words presented in the preceding list in any order. Recall performance for the two oddball nouns, and peri-oddball nouns, was compared with two randomly selected control nouns. The chosen control nouns, like the oddballs, could not occur within the first five nouns of each list.

We used the protocol of Furlong et al. (1998) to genotype the 5-HTTLPR and identify participants homozygous for either the 1 or the $s$ allele to participate in the behavioral experiment. We preselected participants not carrying the rare Lg and Sg allele, rs25531, because it appears to modify gene expression ( $\mathrm{Hu}$ et al., 2006). We therefore performed restriction enzyme digests with HpaII (Wendland et al., 2006) to identify and exclude Lg or Sg carriers. Thus, we preselected participants homozygous for the 5-HTTLPR, without the rare Lg or Sg alleles. We note preliminary evidence for an additive effect of two polymorphic regions of the 5-HTT gene, the 5-HTTLPR polymorphism and a $17 \mathrm{bp}$ variable number of tandem repeats in second intron (VNTR-2), in influencing 5-HTT expression (Hranilovic et al., 2004). Future studies genotyping and ana- 
lyzing the effects of these additional polymorphisms, or their combined haplotypes, may provide a more comprehensive account of the relative influences of 5-HTT-related polymorphisms on emotional memory.

\section{Results}

We first established that mean recall of control nouns did not differ between groups $\left(F_{(1,26)}=0.550 ; p=0.456\right)$. Next, we tested for the effect of genotype on oddball and peri-oddball memory relative to subject-specific control noun recall (Fig. $1 b)$. A genotype $(\mathrm{s} / \mathrm{s}, 1 / \mathrm{l}) \times$ oddball type (emotional, perceptual) $\times$ position (oddball -1 , oddball, oddball +1$) 2 \times 2 \times 3$ repeated-measures ANOVA revealed that, as described previously (Strange et al., 2003), participants recalled oddball words better than words before or after an oddball $\left(F_{(1.7,21.6)}=16.168 ; p<0.001\right)$, with no other significant main effect or interaction. Contrary to one of the predictions arising out of a modulation of emotional memory hypothesis, 5-HTT genotype did not modulate memory recall for emotional oddballs $\left(F_{(1,26)}=6.24 ; p=0.437\right)$. However, we did observe a specific modulation in a further a priori specified comparison limited to E-1. Here we observed worse recall in $s / s$ than in $1 / 1$ subjects $\left(F_{(1,26)}=4.865 ; p=0.036\right)$. In effect, s/s carriers demonstrated a significant E-1 amnesia $\left[t_{(13)}=-2.105 ; p=0.0275\right.$ (one tailed)], whereas $1 / 1$ subjects did not $\left[t_{(13)}\right.$ $=0.911 ; p=0.379$ (two tailed)] (Fig. 1b), supporting our prediction that $1 / 1$ subjects show attenuated emotional modulation of memory compared with $\mathrm{s} / \mathrm{s}$ subjects. Genotype-specific E-1 effects were independent of sex, as revealed by a genotype $(\mathrm{s} / \mathrm{s}, 1 / \mathrm{l}) \times \operatorname{sex}($ male, female $) 2 \times 2$ repeated-measures ANOVA limited to E-1 $\left(F_{(1,6)}=0.732 ; p=0.425\right)$. There was no genotype-dependent difference in memory for perceptual oddballs $\left(F_{(1,26)}=\right.$ $0.060 ; p=0.809)$.

We next compared the effect of genotype on stimulus-specific reaction times (RTs). As shown in Figure 2, RTs to E nouns, relative to control noun RTs, did not differ between s/s and 1/1 groups $\left(F_{(1,26)}=0.060 ; p=0.809\right)$, indicating that greater forgetting of $\mathrm{E}-1$ nouns in the s/s group cannot be attributable to differential genotype-dependent visuomotor responses to the $\mathrm{E}$ nouns.

\section{Discussion}

Our data provide the first demonstration of a clear emotional memory correlate of a 5-HTT polymorphism. However, the effects of the 5-HTTLPR on 5-HT function are currently unclear.

Although early studies report an association between the s allele and decreased 5-HTT mRNA transcription (Heils et al., 1996) and 5-HTT binding (Heinz et al., 2000), recent, larger in vivo single-photon emission computed tomography (Shioe et al.,

$\begin{array}{llllll}P-1 & P & P+1 & E-1 & E & E+1\end{array}$ ... farmer .. crop .. wheat .. oats .. rice .. barley .. harvest .. rape .. seed ..

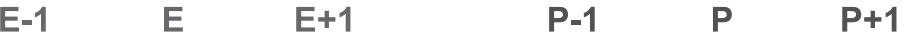
$\begin{array}{llllll}\text { P-1 } & \mathbf{P} & \mathbf{P}+1 & \mathrm{E}-1 \quad \mathrm{E} & \mathrm{E}+1\end{array}$ ... pram .. delivery .. cradle.. mother .. baby .. kid .. abortion .. midwife ...
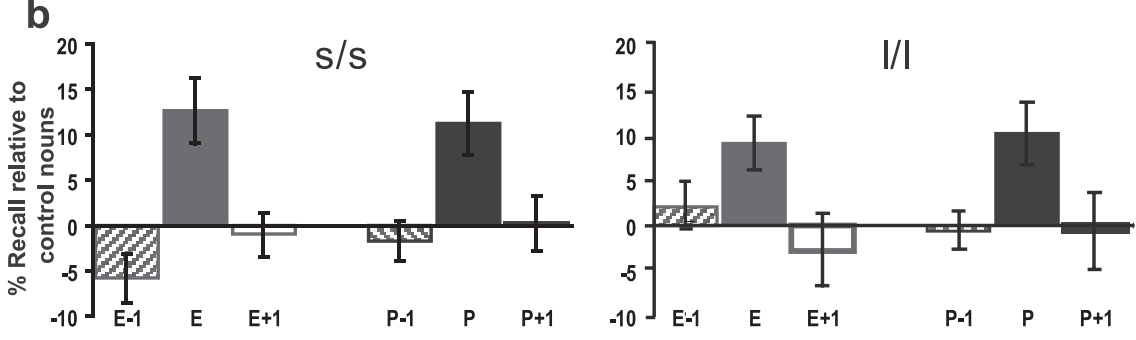

Figure 1. Emotion-induced retrograde amnesia is determined by 5-HTT polymorphism. $\boldsymbol{a}$, Examples of presented nouns. $\boldsymbol{b}$, Mean percentage recall performance $\pm S E M$ relative to control nouns for $E$ and $P$ oddballs and for words presented immediately before and after these oddballs $(-1$ and +1 , respectively), for $s / s$ (left) and $I / I$ (right) groups. Recall performance (mean

a

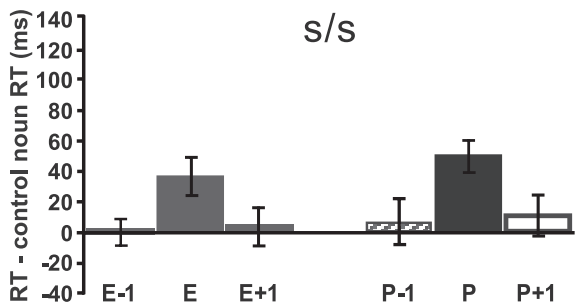

Figure 2. 5-HTT polymorphism does not affect RTs to emotional nouns. There was no genotype-dependent difference in RTs between $\mathrm{s} / \mathrm{s}$ and $\mathrm{I} / \mathrm{I}$ groups to $\mathrm{E}$ nouns $\left(F_{(1,26)}=1.069 ; p=0.311\right)$, indicating that the observed genotype-dependent memory ifferences for $\mathrm{E}-1$ nouns are unlikely to be driven by differential visuomotor responses to the $\mathrm{E}$ nouns. However, a genotype $(\mathrm{s} / \mathrm{s}$, NOVA for RTs revealed a significant main effect of oddball type $\left(F_{(1,13)}=16.339 ; p=0.001\right)$ and position $\left(F_{(1.7,22.0)}=37.684\right.$; ) and a significant genotype $\times$ position interaction $\left(F_{(2,26)}=4.602 ; p=0.019\right)$, with no other significant main effect nouns $\left(F_{(1,26)}=4.755 ; p=0.038\right)$, an unexpected observation requiring further investigation. RTs (mean ms; SEM) to control nouns did not differ between $\mathrm{s} / \mathrm{s}(786.3 ; 23.2)$ and $\mathrm{I} / \mathrm{I}(780.6 ; 33.6)$ groups $\left(F_{(1,26)}=0.022 ; p=0.883\right)$.

2003) and positron emission tomography (Parsey et al., 2006) studies fail to demonstrate reduced 5-HTT binding potential in $\mathrm{s}$ allele carriers. Regardless, there is a remarkably consistent effect of the 5-HTTLPR on amygdala function (Munafò et al., 2008), which may be driven by effects of the polymorphism on downstream targets such as the $5-\mathrm{HT}_{1 \mathrm{a}}$ receptor (David et al., 2005; Hariri and Holmes, 2006). Despite these previous observations of enhanced amygdala responses to emotional stimuli in s carriers (Hariri et al., 2002; Munafò et al., 2008), and that enhanced amygdala activation to emotional stimuli predicts enhanced memory in the same task used here (Strange and Dolan, 2004), we did not observe enhanced memory for E nouns in s/s versus 1/1 groups. In contrast, emotion-induced memory impairment for E-1 stimuli, an effect also dependent on the amygdala (Strange et al., 2003), was only seen in the s/s group.

That 5-HTT polymorphism effects are limited to E-1 amnesic effects contrasts with pharmacological blockade of $\beta$-adrenergic receptors, which abolishes both E-1 amnesia and enhanced E 
memory (Strange et al., 2003). These observations point to a high degree of complexity in emotional memory regulation with a possibility of dissociable roles for serotonergic and noradrenergic systems in emotional memory enhancement and impairment (i.e., E-1). However, it must be noted that propranolol, the $\beta$-adrenergic antagonist typically used in studies of emotional memory (Cahill et al., 1994; Strange et al., 2003), is also a potent antagonist of 5- $\mathrm{HT}_{1 \mathrm{a}}$ receptors (Oksenberg and Peroutka, 1988), perhaps further implicating the serotonergic system in emotional memory regulatory roles previously attributed to noradrenaline. This possibility is further supported by the suggestion that the effect of the 5-HTTLPR on amygdala function (Munafò et al., 2008 ) is driven by effects of the polymorphism on downstream 5- $\mathrm{HT}_{1 \mathrm{a}}$ receptors (David et al., 2005; Hariri and Holmes, 2006).

A distinction is made between influences of valence and arousal effects of emotion on memory (Kensinger and Corkin, 2004). The absence of 5-HTT polymorphism effects on emotional memory encoding could alternatively be explained by the suggestion that memory enhancement effects are arousal mediated (Strange et al., 2003; Kensinger and Corkin, 2004). In contrast, retrograde amnesic effects are valence dependent, in that they are only observed for stimuli preceding a negative or aversive event (Hurlemann et al., 2005). Thus, another explanation for the highly specific effects we observe relates to the proposal that 5-HT mediates an aversive "signal" (Deakin and Graeff, 1991), evoked by the E noun, which disrupts memory for preceding items. The fact that this signal is expressed solely in s/s subjects may again reflect differential 5-HT receptor function in response to the phasic 5-HT signal. This may be attributable to group differences in the phasic signal itself, baseline receptor availability, or levels of expression between 5-HT receptor subclasses (David et al., 2005; Hariri and Holmes, 2006). Indeed, our suggestion that the observed 5-HTT effects can be explained in terms of valence is broadly in accord with proposed roles for 5-HTT polymorphism in cognitive control and modulation of amygdala-prefrontal connectivity (Heinz et al., 2005; Izquierdo et al., 2007).

Our data are further supported by the independent observations that $\mathrm{s} / \mathrm{s}$ genotype is associated with anxiety traits (Lesch et al., 1996) and that experimental subjects with anxiety trait show augmented E-1 amnesia (Miu et al., 2005). Similarly, recent data suggest that the development of posttraumatic stress disorder (PTSD) is more likely to occur in s/s individuals (Lee et al., 2005; Kilpatrick et al., 2007). The inability to recall that a previous pavlovian association has undergone extinction (i.e., impaired extinction recall) has been observed in PTSD patients (Milad et al., 2008) as well as 5-HTT knock-out mice (Wellman et al., 2007). In keeping with the current findings, models of PTSD suggest that peritraumatic amnesia for events temporally proximate to the traumatic event, such as those immediately preceding the emotional event, are central to PTSD pathogenesis (Layton and Krikorian, 2002), and here we demonstrate that s/s subjects demonstrate enhanced amnesia for these preceding items.

We also demonstrate that 5-HTTLPR does not affect memory for neutral nouns, an observation that contrasts with a polymorphism of the $5-\mathrm{HT}_{2 \mathrm{a}}$ receptor, which is reported as having significant effects on episodic memory for neutral stimuli (de Quervain et al., 2003). Although differing levels of synaptic 5-HT produced by the 5 -HTTLPR are likely to modulate $5-\mathrm{HT}_{2 \mathrm{a}}$ receptor activity, evidence from mouse with a knock-out for the 5-HTT indicate that expression levels of major 5-HT receptor subclasses including the $5-\mathrm{HT}_{2 \mathrm{a}}$ receptor also change, possibly because of compensatory regulation (for review, see Hariri and Holmes, 2006). Thus, the lack of 5-HTT polymorphism modulation of neutral noun memory in the current experiment might be explained by compensatory expression differences in 5-HT receptor subtypes caused by differential relative activity of 5-HTT, yielding no net effect on neutral memory. Interestingly, a deletion variant of the $\alpha_{2 b}$-adrenoceptor is implicated in enhanced memory for emotional events (de Quervain et al., 2007). Together with the current findings, this suggests that many genes contribute to emotional memory, as indeed many genes are implicated in affective disorders (Hattori et al., 2005; Levinson, 2006).

\section{References}

Cahill L, Prins B, Weber M, McGaugh JL (1994) beta-Adrenergic activation and memory for emotional events. Nature 371:702-704.

Cahill L, Babinsky R, Markowitsch HJ, McGaugh JL (1995) The amygdala and emotional memory. Nature 377:295-296.

Canli T, Lesch K-P (2007) Long story short: the serotonin transporter in emotion regulation and social cognition. Nat Neurosci 10:1103-1109.

David SP, Murthy NV, Rabiner EA, Munafó MR, Johnstone EC, Jacob R, Walton RT, Grasby PM (2005) A functional genetic variation of the serotonin (5-HT) transporter affects $5-\mathrm{HT}_{1 \mathrm{~A}}$ receptor binding in humans. J Neurosci 25:2586-2590.

Deakin JFW, Graeff FG (1991) 5-HT and mechanisms of defence. J Psychopharmacol 5:305-315.

de Quervain DJF, Henke K, Aerni A, Coluccia D, Wollmer MA, Hock C, Nitsch RM, Papassotiropoulos A (2003) A functional genetic variation of the 5-HT2a receptor affects human memory. Nat Neurosci 6:1141-1142.

de Quervain DJF, Kolassa I-T, Ertl V, Onyut PL, Neuner F, Elbert T, Papassotiropoulos A (2007) A deletion variant of the $\alpha 2 \mathrm{~b}$-adrenoceptor is related to emotional memory in Europeans and Africans. Nat Neurosci 10:1137-1139.

Furlong RA, Ho L, Walsh C, Rubinsztein JS, Jain S, Paykel ES, Easton DF, Rubinsztein DC (1998) Analysis and meta-analysis of two serotonin transporter gene polymorphisms in bipolar and unipolar affective disorders. Am J Med Genet 81:58-63.

Hariri AR, Holmes A (2006) Genetics of emotional regulation: the role of the serotonin transporter in neural function. Trends Cogn Sci 10:182-191.

Hariri AR, Mattay VS, Tessitore A, Kolachana B, Fera F, Goldman D, Egan MF, Weinberger DR (2002) Serotonin transporter genetic variation and the response of the human amygdala. Science 297:400-403.

Hattori E, Liu C, Zhu H, Gershon ES (2005) Genetic tests of biologic systems in affective disorders. Mol Psychiatry 10:719-740.

Heils A, Teufel A, Petri S, Stöber G, Riederer P, Bengel D, Lesch KP (1996) Allelic variation of human serotonin transporter gene expression. J Neurochem 66:2621-2624.

Heils A, Mößner R, Lesch KP (1997) The human serotonin transporter gene polymorphism-basic research and clinical implications. J Neural Transm 104:1005-1014.

Heinz A, Jones DW, Mazzanti C, Goldman D, Ragan P, Hommer D, Linnoila M, Weinberger DR (2000) A relationship between serotonin transporter genotype and in vivo protein expression and alcohol neurotoxicity. Biol Psychiatry 47:643-649.

Heinz A, Braus DF, Smolka MN, Wrase J, Puls I, Hermann D, Klein S, Grüsser SM, Flor H, Schumann G, Mann K, Büchel C (2005) Amygdalaprefrontal coupling depends on a genetic variation of the serotonin transporter. Nat Neurosci 8:20-21.

Hranilovic D, Stefulj J, Schwab S, Borrmann-Hassenbach M, Albus M, Jernej B, Wildenauer D (2004) Serotonin transporter promoter and intron 2 polymorphisms: relationship between allelic variants and gene expression. Biol Psychiatry 55:1090-1094.

Hu XZ, Lipsky RH, Zhu G, Akhtar LA, Taubman J, Greenberg BD, Xu K, Arnold PD, Richter MA, Kennedy JL, Murphy DL, Goldman D (2006) Serotonin transporter promoter gain-of-function genotypes are linked to obsessive-compulsive disorder. Am J Hum Genet 78:815-826.

Hurlemann R, Hawellek B, Matusch A, Kolsch H, Wollersen H, Madea B, Vogeley K, Maier W, Dolan RJ (2005) Noradrenergic modulation of emotion-induced forgetting and remembering. J Neurosci 25:6343-6349.

Izquierdo A, Newman TK, Higley JD, Murray EA (2007) Genetic modula- 
tion of cognitive flexibility and socioemotional behavior in rhesus monkeys. Proc Natl Acad Sci U S A 14128-14133.

Kensinger EA, Corkin S (2004) Two routes to emotional memory: distinct neural processes for valence and arousal. Proc Natl Acad Sci U S A 101:3310-3315

Kilpatrick DG, Koenen KC, Ruggiero KJ, Acierno R, Galea S, Resnick HS, Roitzsch J, Boyle J, Gelernter J (2007) The serotonin transporter genotype and social support and moderation of posttraumatic stress disorder and depression in hurricane-exposed adults. Am J Psychiatry 164:1693-1699.

Layton B, Krikorian R (2002) Memory mechanisms in posttraumatic stress disorder. J Neuropsychiatry Clin Neurosci 14:254-261.

Lee HJ, Lee MS, Kang RH, Kim H, Kim SD, Kee BS, Kim YH, Kim YK, Kim JB, Yeon BK, Oh KS, Oh BH, Yoon JS, Lee C, Jung HY, Chee IS, Paik IH (2005) Influence of the serotonin transporter promoter gene polymorphism on susceptibility to posttraumatic stress disorder. Depress Anxiety 21:135-139.

Lesch KP, Bengel D, Heils A, Sabol SZ, Greenberg BD, Petri S, Benjamin J, Müller CR, Hamer DH, Murphy DL (1996) Association of anxietyrelated traits with a polymorphism in the serotonin transporter gene regulatory region. Science 274:1527-1531.

Levinson DF (2006) The genetics of depression: a review. Biol Psychiatry 60:84-92.

Milad MR, Orr SP, Lasko NB, Chang Y, Rauch SL, Pitman RK (2008) Presence and acquired origin of reduced recall for fear extinction in PTSD: results of a twin study. J Psychiatr Res 42:515-520.

Miu AC, Heilman RM, Opre A, Miclea M (2005) Emotion-induced retrograde amnesia and trait anxiety. J Exp Psychol Learn Mem Cogn 31:1250-1257.

Munafò MR, Brown SM, Hariri AR (2008) Serotonin transporter (5HTTLPR) genotype and amygdala activation: a meta-analysis. Biol Psychiatry 63:852-857.
Oksenberg D, Peroutka SJ (1988) Antagonism of 5-hydroxytryptamine1A (5-HT1A) receptor-mediated modulation of adenylate cyclase activity by pindolol and propranolol isomers. Biochem Pharmacol 37:3429-3433.

Parsey RV, Hastings RS, Oquendo MA, Hu X, Goldman D, Huang Y-y, Simpson N, Arcement J, Huang Y, Ogden RT, Van Heertum RL, Arango V, Mann JJ (2006) Effect of a triallelic functional polymorphism of the serotonin-transporter-linked promoter region on expression of serotonin transporter in the human brain. Am J Psychiatry 163:48-51.

Ressler KJ, Mayberg HS (2007) Targeting abnormal neural circuits in mood and anxiety disorders: from the laboratory to the clinic. Nat Neurosci 10:1116-1124

Rhodes RA, Murthy NV, Dresner MA, Selvaraj S, Stavrakakis N, Babar S, Cowen PJ, Grasby PM (2007) Human 5-HT transporter availability predicts amygdala reactivity in vivo. J Neurosci 27:9233-9237.

Shioe K, Ichimiya T, Suhara T, Takano A, Sudo Y, Yasuno F, Hirano M, Shinohara M, Kagami M, Okubo Y, Nankai M, Kanba S (2003) No association between genotype of the promoter region of serotonin transporter gene and serotonin transporter binding in human brain measured by PET. Synapse $48: 184-188$.

Strange BA, Dolan RJ (2004) $\beta$-Adrenergic modulation of emotional memory-evoked human amygdala and hippocampal responses. Proc Natl Acad Sci U S A 101:11454-11458.

Strange BA, Hurlemann R, Dolan RJ (2003) An emotion-induced retrograde amnesia in humans is amygdala- and $\beta$-adrenergic-dependent. Proc Natl Acad Sci U S A 100:13626-13631.

Wellman CL, Izquierdo A, Garrett JE, Martin KP, Carroll J, Millstein R, Lesch KP, Murphy DL, Holmes A (2007) Impaired stress-coping and fear extinction and abnormal corticolimbic morphology in serotonin transporter knock-out mice. J Neurosci 27:684-691.

Wendland JR, Martin BJ, Kruse MR, Lesch KP, Murphy DL (2006) Simultaneous genotyping of four functional loci of human SLC6A4, with a reappraisal of 5-HTTLPR and rs25531. Mol Psychiatry 11:224-226. 